\title{
The Future of Sustainability
}

\author{
Ralf Lüfter \\ Free University of Bolzano
}

\begin{abstract}
The focus of the present research is not on expected developments that are by one means or another linked to the concept of sustainability and to questions, whether current sustainability-models are fit for the future, so that they can be employed as corrective or functional factors applicable to the planning and governance of predictable scenarios in the field of ecology, economy, and social issues. But the focus lies on questions like: How does the concept of sustainability relate to the future? How is the future as such affected and conditioned by the concept of sustainability? To what extent is the concept of sustainability open to the future and how can the concept of sustainability conceive of something like the future? The aim of the paper is therefore to clarify and better understand what is at stake when we address a sustainable future, i.e. a future under the conditions of an economy, of a technology, of a science that is supposed to be sustainable. The paper is based on a distinction that has its part in the tradition of ethics with far-reaching consequences for what throughout this tradition was called into question namely: the ethos (the dimension of the human being). It is the distinction between two aspirant principles. In terms of form, the one allows and sustains accomplishment, whereas the other doesn't. As for the former, the reference is mainly to classical ethical positions (on the one hand Plato and Aristotle, on the other hand Kant). As for the latter, on which the focus of this research lies, a phenomenological analysis of the concept of sustainability might help in its comprehension as well as in the understanding of the way in which we, today, by complying with it, conceive of something like an open future.
\end{abstract}

Keywords: sustainability ethics, environmental ethics, future, phenomenology

The nature of the following presentation remains introductory. Its aim is to raise a specific question by touching upon some of its constitutive elements. Accordingly the presentation will be confined to only two remarks: the first—a preliminary remark—concerning the proposed topic; the second —a more defining remark-concerning the frame of references within which this topic has its place and from where it might be addressed to and further developed. As we will presently see, both remarks are introductory; it is true, but nonetheless they lead us straight to the heart of the phenomenon in question-namely, the future of sustainability.

It is characteristic of our epoch that the claim of what is commonly called the sustainability imperative is admitted and adopted in almost all fields of human action. Sustainability is not only a prominent term in public and academic discussions but beyond that over the last decades it has become the guiding value of our time.

Ralf Lüfter, Ph.D., assistant professor of Moral Philosophy, Faculty of Economics and Management, Free University of Bolzano, Italy; main research fields: Ethics, Philosophy of Economics, Theory of Science, and Phenomenology. Email: rluefter@unibz.it.

Paper presented at the European Science Foundation "Rights to a Green Future” final Conference, Soesterberg (Netherlands), October 2014, and at the Luncheon Research Series at the Free University of Bozen-Bolzano (Italy), December 2014. The text maintains the oral style of the presentation. 
Most commonly we know the concept of sustainability in its specific modern sense that has emerged since the 1980s by its prominent place within important documents of the United Nations concerning strategies for the future such as the Brundtland-Report (1987)—titled not by chance Our Common Future—or the Agenda 21 (1992). Both documents provide a response to The Limits to Growth (1972) published on the initiative of the Club of Rome. Recently released documents by the European Commission (2011) dealing with a renewed strategy for Corporate Social Responsibility refer to sustainability as a condition of possibility for having a future capable of welcoming and hosting humanity.

Now, in order to set out on the right path, we should consider our topic more closely, shedding some light on how it is understood in the context of this paper. What is at issue here- "the future of sustainability" - can be taken in at least two different ways. At first glance the question seems to display an interest in expected developments that are by one means or another linked to the concept of sustainability. As a direct consequence of such an interest, we might, for example, question whether and to what extent the concept of sustainability will be an issue in future discussions and future decision-making processes. Or we might, for instance, question, whether and to what extent current sustainability-models are fit for the future, so that they can be employed as corrective or functional factors applicable to the planning and governance of predictable scenarios in the field of ecology, in the field of economy, and in the field of social issues.

However, the point in question can also be understood in a different way and direct us towards issues that differ significantly from those already mentioned and thus touch upon something that is far from the above-mentioned interest in expected developments. In particular questions like: How does the concept of sustainability itself relate to the future? How is the future as such affected and conditioned by the concept of sustainability? To what extent is the concept of sustainability open to the future and how can the concept of sustainability conceive of something like an open future? Now, we have to state that: Firstly, the intention is to place the focus of the present research exclusively on these latter questions; secondly, as a consequence, its aim is that to clarify and better understand what actually is at stake when addressing the future under the conditions of an economy, of a technology, of a science that is supposed to be sustainable.

In order to appropriately integrate the above-mentioned questions, we have to consider the frame of references in which these questions arise within our epoch. We do so by considering, for now, just two references.

The first reference is the one to normative sciences as they have constituted themselves throughout modernity, addressing in the first place the fundamental question raised, not least, by Immanuel Kant in a frequently cited passage of the Critique of the Pure Reason: "All the interests of my reason (speculative as well as practical) combine in the following three questions: 1. What can I know? 2. What ought I to do? 3. What may I hope" (2011, A 804-A805)? ${ }^{1}$

"What ought I to do" is referred to as the core question of a form of knowledge that considers normative principles supposed to provide orientation, "by telling do this or that, and abstain from doing the other" (2011, A96-A97). ${ }^{2}$

The second reference is the one made to the way of acceptance and consequent response to this question by our epoch and thus the determination of our present notion of responsibility informed by the concept of sustainability.

"Epoch," here, does not denote any "span of time," "period of time,” or any "duration between two 
moments in time”- but it has to be understood in its original sense derived from the Greek word $\dot{\varepsilon} \pi$ ¿x - that literally spoken means retention, suspension. What retains itself and thus remains suspended in such a way that our thinking is consistently attracted and tempted by it — what retains itself and thus remains suspended in such a way that its suspension constitutes the pensum-is what has to be pondered over, what has to be thought about, and what therefore remains the constant source of any genuine research. Since antiquity, this source has been called the truth. In other words, truth is the always new, the always attracting and tempting source of thinking that presents itself throughout its suspension as the pensum, claiming attempts to say it (to say the truth) and thereby generating its own tradition. The Latin word pensum in fact includes what is weighed up in the sense of what has to be pondered over and what has to be thought about: something that has to be pondered over presents itself as something that is still un-decided; something that has to be thought about presents itself as something that is still un-thought. What is, in this sense, un-decided and un-thought and therefore suspended, brings itself into the presence of an immediate reference to the future. Insofar as we assert that it is characteristic of our epoch that the claim of the sustainability imperative is admitted and adopted in almost all fields of human action and that consequently its normative implications determine our presence, we assert withal that the concept of sustainability itself refers to the future in the above-mentioned sense. And this is exactly the way we address "the future of sustainability."

The future, together with the present and the past, forms the characteristic of time. Most commonly we know about it by way of an accepted notion of time on the basis of which the past and the future are opposed to each other as the earlier and the later distinct from the now. Thus, by implication, the present is understood in terms of the now. In his lecture on Time and Being, held at the Studium Generale at the University of Freiburg in 1962, Martin Heidegger introduces an example that immediately displays a seminal distinction concerning this common notion of time. "We might e.g., read somewhere the notice: 'The celebration took place in the presence of many guests'... we never say and we cannot say: "The celebration took place in the now of many guests" $(2000,10){ }^{3}$

As long as we persist with the commonly accepted notion of time within which the present is understood in terms of the now, we omit another, maybe more original notion of time. Nonetheless if we are to characterize time in terms of the present, Heidegger asserts, we usually understand the present in terms of the now as distinct from the no-longer-now of the past and the not-yet-now of the future. As we have learned from the example, the commonly accepted notion of time falls short if the present has to be thought of in terms of presence. "We are not accustomed to defining the peculiar character of time with regard to the present in the sense of presence. Rather, we represent time... in terms of the now” $(2000,12){ }^{4}$

However, the present in the sense of presence differs so vastly from the present in the sense of the now that the present as presence can in no way be determined in terms of the present as the now. The reverse would rather seem possible... If such were the case, the present as presence and everything which belongs to such a present would have be called true time, even though there is nothing immediately about it of time as time is commonly represented in the sense of a succession of a calculable sequence of nows. ${ }^{5}(2000,12)$

From this it follows that when the present is no longer represented in terms of the now, the future can no longer be understood as the mere not-yet-now. But the future has to be thought of by way of the present in terms of presence-namely, a presence that includes the absence of what is to be. If one looks it up in the Oxford English Dictionary, one will find that "Future" means: "what is to be"-in the sense of: "what is 
approaching," "what is coming," or "what is nighing." We tend to ignore what is actually said here-namely, that the absence of what is to be asserts its presence-that is to say, a presence thanks to which the future concerns us, thanks to which we become aware of the future as the approaching, as the coming, or as the nighing.

In a previous lecture, held in 1957, again at the Studium Generale at the University of Freiburg, Heidegger elucidates this correlation in the following way:

By presence here, we do not mean what is contingently present-at-hand in the momentary now. Presence (in the sense of the German word "Gegen-wart”) is what waits towards us, waits for whether and how we expose ourselves to it or, contrarily, close ourselves off from it. That which waits towards us approaches us (comes towards us); it is the future (in the sense of the German word "Zu-kunft”), rightly thought. It holds sway over the presence as an imposition that approaches the Da-sein of the human being encouraging him in one way or another, so that he would sense the future with its claim. Only in the atmosphere of such an encouraged sensing does questioning thrive, that essential questioning that belongs to the bringing forth of every genuine work in any field whatsoever. ${ }^{6}(2005,83)$

Again, future here is not thought of as the mere not-yet-now that sooner or later will pass by and thus become the past in terms of the no-longer-now, but as something that approaches us, that comes towards us, or that reaches us through a claim that concerns us, lying ahead of us, awaiting us-in other words, through a concrete sense suspended as the pensum of every human thinking and acting.

These few remarks should help us now to roughly outline the frame of references within which the proposed topic has its place and from where it may be addressed. The first reference is, as mentioned earlier, the reference to normative sciences as they have constituted themselves in the modern age by posing the question: "What ought I to do?"

Through the "ought," we are reached by a claim expecting a response, waiting for whether we expose ourselves to it or not, waiting for whether we admit it and adopt it or not, waiting for our responsibility. As Kant argues, this "ought" is constantly saying do this or that, and abstain from doing the other. Accordingly it sets the tone for what is to be, for what is, in its constant absence, present, claiming realisation, claiming accomplishment. The above-mentioned concrete sense suspended as the pensum of thinking and acting is therefore ab initio exalted as a sense that ought to be realised, that ought to be accomplished. Independently of his own groundwork and his own attempt to lay the foundations of the said exaltation, Kant recognises therein the first formal ground of what presents itself in the fundamental question of normative sciences. In a striking passage of one of his pre-critical writings, Kant argues that "The formula by means of which any such claim is expressed is this: One ought to do this or that and abstain from doing the other” (2011, A 96-A97). ${ }^{7}$

And he continues with a plain as well as remarkable distinction:

Now, every ought to expresses a necessity of the action and is capable of two meanings. To be specific, either I ought to do something (as a means) if I want something else (as an end), or I ought immediately do something else (as an end) and realize it. The former may be called the necessity of the means (necessitas problematicam), and the latter the necessity of the ends (necessitas legalem). The first kind of necessity does not indicate any obligation at all. It merely specifies a prescription as the solution to the problem concerning the means I must employ if I am to attain a certain end. If one person tells another what action he must perform or what actions, he must abstain from performing if he wishes to advance his happiness, he might perhaps be able, I suppose, to subsume all the teaching of morality under his prescriptions. They are not, however, obligations any longer except in the sense in which it would be my obligation to draw two intersecting arcs if I wanted to bisect a straight line into two equal parts. In other words, they would not be obligations at all; they would simply be recommendations to adopt a suitable procedure, if one wished to attain a given end. Now since no other necessity attaches to the employment of means than that which belongs to the end, all the actions which are prescribed by 
morality under the conditions of certain ends are contingent. They cannot be called obligations as long as they are not subordinated to an end necessary in itself. ${ }^{8}$ (2001, A 96-A 97)

In the quoted passage, Kant refrains from defining more closely what the asserted necessity consists of-he concludes his reasoning however by saying: “... the proposition: abstain from doing that which will hinder the realization of the greatest achievable accomplishment” (2011, A 96-A97), ${ }^{9}$ i.e., realizing the greatest accomplishment that is achievable through you, is the first formal ground of any obligation to act. The specific sense is suspended and in its suspension exalted as what ought to be, it has the form of the greatest achievable accomplishment that may be realised through us, i.e., that may be realised, each time, through a single and in its singularity unique and incomparable human being.

Returning to what we have already said about what approaches us, what comes towards us, what reaches us by the presence of a claim that concerns us, we may argue that the here intended concrete sense has got the form of an achievable accomplishment, and thus it is ab initio conceived of as something that is accomplishable itself. In the light of the formal principle introduced, anything is seen in its ability to sustain the realisation of this accomplishment. In the context of the traditional hierarchy between ethics and economics, ethics had to question the ends that ought to be achieved, while economics was seen as "the sciences of the means towards the achievement of these ends." 10

Now, the second reference is made to the way of acceptance and adoption and consequent response to the fundamental question of normative sciences by our epoch and the determination in further consequence of our main notion of responsibility—namely, the concept of sustainability. According to what we have said, so far we may ask: Under the dominance of which claim can sustainability be conceived of as the guiding principle of our epoch - respectively as a condition for the possibility of having a future capable of welcoming and hosting humanity? And we may answer: The sustainability imperative has not by chance arisen in the context of a discussion preoccupied with the limits to growth preoccupied with the impending danger of a growth that reaches its own limits and thus being at risk of expiring. According to its original meaning in the field of forestry, sustainability deals with the preservation and provision of all relevant factors that assure the functionality of a system. Tied up with it, everything assumes the sense of a resource-namely, the sense of a means to an end, i.e., the sense of a means capable of sustaining this end, the sense of a means capable of sustaining further growth. Here, growth is seen as a medium for a claim dominant in our time-growth serves and satisfies this claim only by avoiding its own limitation - and it avoids its own limitation by being sustainable. In other words, growth can serve as a medium for the dominant claim of our time only if it is sustainable. In a paper published in 2006 by Ivo De Gennaro, he called the dominant claim of our epoch empowerment to performance.

"Empowerment of performance" means: imparting the power or command over effects and enabling the implementation of the enhancement of effectiveness (i.e., the capacity for producing effects). According to this trait, the truth, and validity of anything that is, including the truth and validity of all human knowledge and action, is determined by the capacity for and the degree of this empowerment. ${ }^{11}(2006,79)$

Sense is given exclusively to what is capable of sustaining the implementation of empowerment to performance and thus serving as a constantly elevated degree of its secured enhancement of effectiveness. The claim that calls for a realisation of this dominant trait is cut off from any reference to accomplishment and thus no longer concerned with it, i.e., no longer concerned with what Kant took on as the first formal ground of any 
obligation to act and what in the context of traditional ethics was called an end by itself. On condition that the empowerment to performance is the dominant trait of our epoch, we might say that the presence of what is to be might be characterised as inherently unaccomplishable, as suffering a constant insufficiency—namely, the insufficiency of commanded performance. Consequently "to act" means to carry out an effect-namely, the effect of eliminating a recurrent deficit of power, which, however, never brings us closer to any form of accomplishment. In this sense, what approaches us, what comes towards us, or what reaches us through the presence of a claim that finds its voice in the sustainability imperative is the suffering of a constant insufficiency-an insufficiency that is characterised and consists of the suspension of any form of accomplishment. $^{12}$

\section{Notes}

1. "Alles Interesse meiner Vernunft (das spekulative sowohl, als das praktische) vereinigt sich in folgenden drei Fragen: 1 . Was kann ich wissen? 2. Was soll ich tun? 3. Was darf ich hoffen?” Immanuel Kant, Kritik der reinen Vernunft (KrV), A 804-A 805.

2. "Man soll dieses oder jenes tun und das andre lassen." Immanuel Kant, Untersuchung über die Deutlichkeit der Grundsätze der natürlichen Theologie und der Moral (Nat. Theol.), A 96-A 97.

3. “Wir lesen z.B. irgendwo die Mitteilung: 'In Anwesenheit zahlreicher Gäste wurde das Fest gefeiert'... Wir sagen denn auch niemals und können es auch nicht sagen: ‘Im Jetzt zahlreicher Gäste wurde das Fest gefeiert.” Martin Heidegger, Zeit und Sein, in: Ders., Zur Sache des Denkens, Niemeyer: Tübingen 2000, S. $10 f$.

4. "Indes sind wir es nicht gewohnt, das Eigene der Zeit aus dem Hinblick auf die Gegenwart im Sinne der Anwesenheit zu bestimmen. Vielmehr wird die Zeit vom Jetzt her vorgestellt.” Martin Heidegger, Zeit und Sein, Ders., Zur Sache des Denkens, Niemeyer: Tübingen 2000, S. 11.

5. "Allein die Gegenwart im Sinne der Anwesenheit ist von der Gegenwart im Sinne des Jetzt so weitgehend verschieden, daß sich die Gegenwart als Anwesenheit auf keine Weise von der Gegenwart als dem Jetzt her bestimmen läßt. Eher scheint das Umgekehrte möglich... Träfe dies zu, dann müsste die Gegenwart als Anwesenheit und alles, was zu solcher Gegenwart gehört, die eigentliche Zeit heißen, wenngleich sie unmittelbar nichts von der gewöhnlich vorgestellten Zeit im Sinne des Nacheinander der berechenbaren Jetzt-Folge an sich hat.” Martin Heidegger, Zeit und Sein, in: Ders., Zur Sache des Denkens, Niemeyer: Tübingen 2000, S. 12.

6. "Unter Gegenwart verstehen wir hier nicht das im momentanen Jetzt gerade Vorhandene. Gegen-wart ist das, was uns entgegenwartet, wartet, ob und wie wir uns ihr aussetzen oder dagegen verschließen. Was uns entgegen-wartet, kommt auf uns zu, ist die recht gedachte Zu-kunft. Sie durchwaltet die Gegen-wart als eine Zumutung, die das Da-sein des Menschen angeht, ihn so oder so anmutet, damit er sie, die Zu-kunft, in ihrem Anspruch vermute. Erst in der Luft solchen Vermutens gedeiht das Fragen, jenes wesenhafte Fragen, das zur Hervorbringung jedes gediegenen Werkes, auf welchem Feld auch immer, gehört.” Martin Heidegger, Bremer und Freiburger Vorträge, HGA Bd. 79, Klostermann: Frankfurt am Main 2005, S. 83.

7. "Man soll dieses oder jenes tun und das andre lassen; dies ist die Formel, unter welcher eine jede Verbindlichkeit ausgesprochen wird.” Immanuel Kant, Untersuchung über die Deutlichkeit der Grundsätze der natürlichen Theologie und der Moral (Nat. Theol.), A 96-A 97.

8. "Nun drückt jedes Sollen eine Notwendigkeit der Handlung aus und ist einer zwiefachen Bedeutung fähig. Ich soll nämlich entweder etwas tun (als ein Mittel), wenn ich etwas anders (als einen Zweck) will, oder ich soll unmittelbar etwas anders (als einen Zweck) tun und wirklich machen. Das erstere könnte man die Notwendigkeit der Mittel (necessitatem problematicam), das zweite die Notwendigkeit der Zwecke (necessitatem legalem) nennen. Die erstere Art der Notwendigkeit zeigt gar keine Verbindlichkeit an, sondern nur die Vorschrift als die Auflösung in einem Problem, welche Mittel diejenige sind, deren ich mich bedienen müsse, wie ich einen gewissen Zweck erreichen will. Wer einem andern vorschreibt, welche Handlungen er ausüben oder unterlassen müsse, wenn er seine Glückseligkeit befördern wollte, der könnte wohl zwar vielleicht alle Lehren der Moral darunter bringen, aber sie sind alsdann nicht mehr Verbindlichkeiten, sondern etwa so, wie es eine Verbindlichkeit wäre, zwei Kreuzbogen zu machen, wenn ich eine gerade Linie in zwei gleiche Teile zerfällen will, d. i. es sind gar nicht Verbindlichkeiten, sondern nur Anweisungen eines geschickten Verhaltens, wenn man einen Zweck erreichen will. Da nun der Gebrauch der Mittel keine andere Notwendigkeit hat, als diejenige, so dem Zwecke zukommt, so sind so lange alle Handlungen, die die Moral unter der Bedingung gewisser Zwecke vorschreibt, zufällig und können keine Verbindlichkeiten heißen, so lange sie nicht einem an sich notwendigen Zwecke untergeordnet werden.” Immanuel Kant, Untersuchung über die Deutlichkeit der Grundsätze der natürlichen Theologie und der Moral (Nat. Theol.), A 96-A 97.

9. “... der Satz: Unterlasse das, wodurch die durch dich größtmögliche Vollkommenheit verhindert wird...” Immanuel Kant, Untersuchung über die Deutlichkeit der Grundsätze der natürlichen Theologie und der Moral (Nat. Theol.), A 96-A 97. 
10. Ivo De Gennaro, Building Leadership on the Invaluable. Towards the Groundworks for a Phenomenological Approach to the Philosophy of Management, Ancilla Juris (06/78), Klostermann: Frankfurt am Main, 2006, S. 78.

11. Ivo De Gennaro, Building Leadership on the Invaluable. Towards the Groundworks for a Phenomenological Approach to the Philosophy of Management, Ancilla Juris (06/78), Klostermann: Frankfurt am Main 2006, S. 79.

12. For a much more far-reaching and in-depth analysis of the phenomenon see: Ivo De Gennaro, Building Leadership on the Invaluable. Towards the Groundworks for a Phenomenological Approach to the Philosophy of Management, Ancilla Juris (06/78), Klostermann: Frankfurt am Main, 2006, S. 78-87. 